\title{
Variability in Ice Nucleation Strains of Pseudomonas syringae Isolated from Diseased Woody Plants in Pacific Northwest Nurseries
}

\author{
S. BACA, Graduate Research Assistant, M. L. CANFIELD, Research Assistant, and L. W. MOORE, Associate \\ Professor of Plant Pathology, Oregon State University, Corvallis 97331
}

\begin{abstract}
Baca, S., Canfield, M. L., and Moore, L. W. 1987. Variability in ice nucleation strains of Pseudomonas syringae isolated from diseased woody plants in Pacific Northwest nurseries. Plant Disease 71:412-415.
\end{abstract}

Infections incited by Pseudomonas syringae have been reported by nursery operators in many woody plants grown in Pacific Northwest nurseries. In several cases, nursery operators reported that episodes of light freezing temperatures $(0$ to $-5 \mathrm{C})$ preceded or were associated with initial symptom development in aspen and magnolia. Because ice nucleation induced by $P$. syringae has been implicated as a predisposing factor to infection of other woody hosts, the association of the ice nucleation phenotype with $P$. syringae strains recovered from infected woody hosts was examined. Eighty-five percent or more of the strains isolated from linden, lilac, dogwood, and magnolia were ice nucleation active (INA) at $-5 \mathrm{C} ; 76 \%$ of the strains from aspen were active ice nucleators, but only $30 \%$ of the strains from Japanese pear and $24 \%$ of those from red maple were active ice nucleators at $-5 \mathrm{C}$. The $P$. syringae strains recovered from these seven woody hosts were also variable relative to the induction of a hypersensitive response in tobacco and the ability to infect green fruit of yellow pear tomato. The range in hypersensitive responses varied from $100 \%$ in aspen to $57 \%$ in Japanese pear and in pathogenicity from $100 \%$ in aspen to $36 \%$ in magnolia.

Additional key words: frost injury

In recent years, infection by Pseudomonas syringae van Hall of many woody plants grown in Pacific Northwest nurseries has increased both in severity and frequency of occurrence. A survey conducted to determine the distribution of $P$. syringae among plants in 32 nurseries showed that populations of pathogenic strains of $P$. syringae could be recovered from 40 of 44 plant species representing 13 plant families (3). Nursery operators and state nursery inspectors reported that in magnolia and aspen, light freezing temperatures ( 0 to -5 C) preceded or were associated with initial symptom development.

It has been shown that certain strains of $P$. syringae (10), P. fluorescens Migula (12), and Erwinia herbicola (Lohnis) Dye (10) can initiate ice nucleation activity (INA) at temperatures higher than would normally be expected. Frost injury and subsequent damage in susceptible plants frequently occurs (9); however, the association between INA and damage to susceptible tissues by $P$. fluorescens and $E$. herbicola is not clear. This damage to Technical Paper 7791 of the Oregon Agriculture
Experiment Station.

Accepted for publication 13 November 1986 (submitted for electronic processing).

The publication costs of this article were defrayed in part by page charge payment. This article must therefore be hereby marked "advertisement" in accordance with 18 U.S.C. $\$ 1734$ solely to indicate this fact.

๑ 1987 The American Phytopathological Society plant tissues incited by INA $P$. syringae has been reported to predispose apricot, pear, poplar, sour cherry, and peach to infection by $P$. syringae $(8,9,13-18)$. Although epiphytic INA strains of $P$. syringae are apparently widely distributed in nature on healthy plants, no pathogenicity studies were reported for these strains $(1,2,4,7,10)$.

The purpose of this research was to determine 1) the distribution of the INA phenotype within populations of $P$. syringae recovered from different species of infected woody plants and 2) the association of INA with the ability to incite a hypersensitive response (HR) in tobacco or incite pathogenic changes on green fruit of yellow pear tomato.

\section{MATERIALS AND METHODS}

Source and maintenance of bacterial strains. The $P$. syringae strains used in this study were isolated from diseased tissues of woody plants during a 1982-1983 survey. Strains from seven plant species representing seven plant families were tested further and included aspen (Populus tremuloides), lilac (Syringa vulgaris), linden (Tilia cordata), magnolia (Magnolia soulangiana), Japanese pear (Pyrus spp.), dogwood (Cornus florida), and maple (Acer rubrum). All strains isolated in this survey were stored as working cultures on slants of potato-dextrose agar amended with $0.1 \%(\mathrm{w} / \mathrm{v})$ chloranthalonil to riduce fungal contamination and $0.5 \%$ (w/v) $\mathrm{CaCo}_{3}$ as a buffering agent. For long-term storage, bacteria in a mixture of sterile glycerol and deionized distilled water $30 / 70 \%(\mathrm{v} / \mathrm{v})$ were stored in $1-\mathrm{ml}$ aliquots at $-70 \mathrm{C}$.

Characterization of strains. Strains were characterized as $P$. syringae by the methods of Canfield et al (3). Further characterization included pathogenicity (2) and INA $(10,11)$.

Inoculum preparation. Bacterial inoculum was prepared by streaking slants of King's medium B and incubating slants at $24 \mathrm{C}$ for $48 \mathrm{hr}$. Aqueous suspensions of cells were used in testing for INA, pathogenicity, and hypersensitivity $(2,8,10)$.

INA. The INA was determined by the freeze drop method of Vali as modified by Lindow et al (10). The ability of each strain to induce ice formation at $-5 \mathrm{C}$ was determined by pipetting $1010-\mu 1$ drops of each strain onto a paraffin-coated sheet of aluminum foil. The foil sheet was then floated on a 50:50 solution of propylene glycol and water. This solution was maintained at $-5 \pm 1 \mathrm{C}$ by an Excal 300 controlled-temperature bath. Tests for INA were performed using a $10^{9}$-cfu $/ \mathrm{ml}$ cell suspension.

Pathogenicity to green tomato fruit. The ability of these strains to induce pathogenic changes in green fruit of yellow pear tomato (Lycopersicon esculentum Mill.) was tested by the method of Cameron (2). Three injections of $0.1 \mathrm{ml}$ per fruit of a $10^{6}$-cfu/ml suspension were used and inoculated fruit were placed into a plastic box to increase relative humidity. Fruit were observed for pathogenic changes after 7 days.

HR. The ability of each strain to induce an HR in tobacco (Nicotiana tabacum cv. White Barley) was tested by infiltrating $0.1 \mathrm{ml}$ of a $10^{9}-\mathrm{cfu} / \mathrm{ml}$ suspension into leaves of tobacco and observing after $24 \mathrm{hr}$ for white collapsed areas $(8,16)$. All tests were replicated twice.

\section{RESULTS}

INA strains of $P$. syringae were isolated from 40 of 44 diseased woody plant cultivars that were sampled from 1982 to 1983. A total of 466 fluorescent pseudomonad colonies were selected and characterized. Sixty-five percent $(303 / 466)$ of these pseudomonads were both oxidase and arginine dihydrolase negative (3), the two major characteristics used for presumptive identification of a fluorescent bacterium to the $P$. syringae group (15). 
Fifty-eight percent $(175 / 303)$ of these putative $P$. syringae were positive for INA at $-5 \mathrm{C}$, whereas only $9 \%(16 / 172)$ of the other fluorescent pseudomonads (non- $P$. syringae types) were active ice nucleators at this temperature. None of the $P$. syringae strains isolated from rhododendron, ash, or eucalyptus were INA at $-5 \mathrm{C}$.

Strains from seven plant cultivars representing seven distinct plant families were selected for further characterization to increase the probability of detecting variations in the distribution of the INA phenotype between the different hosts. Of 150 strains of putative $P$. syringae tested from lilac, linden, dogwood, magnolia, Japanese pear, and red maples, $62 \%(93 / 150)$ were active as ice nucleators at -5 C. However, the proportion of INA strains of $P$. syringae strains varied according to the host from which they were isolated (Fig. 1). The percentage of INA strains isolated from each plant species varied from 24 to $94 \%$, and the plant families could be segregated into three classes (high, intermediate, and low) according to the percentage of INA strains recovered from each host. The first class included linden, lilac, dogwood, and magnolia, all of which yielded a high percentage of INA strains (88-94\%). Aspen represented an intermediate class where $76 \%$ of the recovered strains were active as ice nucleators at $-5 \mathrm{C}$. The final group included strains from Japanese pear and red maple that showed a much lower frequency of INA (30 and 24\%, respectively).

Strains of INA $P$. syringae from different hosts were also variable relative to inducing an HR in tobacco leaves and in infecting green fruit of yellow pear tomato (Fig. 2). A mean of $85 \%$ (79/93) of all INA $P$. syringae strains induced an HR in tobacco, whereas only $69 \%$ $(64 / 93)$ of these strains were pathogenic on tomato fruit. Thus the HR was the best indicator of potential pathogenicity, and this pattern held consistent for strains from each of the host species analyzed. The variations between INA and $\mathrm{HR}$ of $P$. syringae strains isolated from the seven plant hosts is shown more clearly in Table 1. Within each subpopulation of $P$. syringae, strains occurred that were either INA, induced an HR in tobacco, or exhibited both traits. In all plant hosts, with the exception of linden and dogwood, strains of $P$. syringae (florescent, oxidase and arginine chlydrolase negative) were isolated that were neither INA nor able to induce an HR in tobacco. These percentages were low in lilac, aspen, and magnolia but markedly increased in Japanese pear and maple.

Whereas the percentage of strains showing INA activity was higher than the percentage of strains producing either an $\mathrm{HR}$ or pathogenic reaction from lilac, linden, magnolia, dogwood, and aspen, the reverse was true for strains from Japanese pear and red maple. For $P$. syringae strains from Japanese pear $(30 \%$ INA), $57 \%$ of the strains induced an HR in tobacco and $50 \%$ were pathogenic on tomato. Only four of 47 strains isolated from red maple (24\% INA) were $P$. syringae types, all four of which induced the HR in tobacco and three which induced pathogenic changes in green

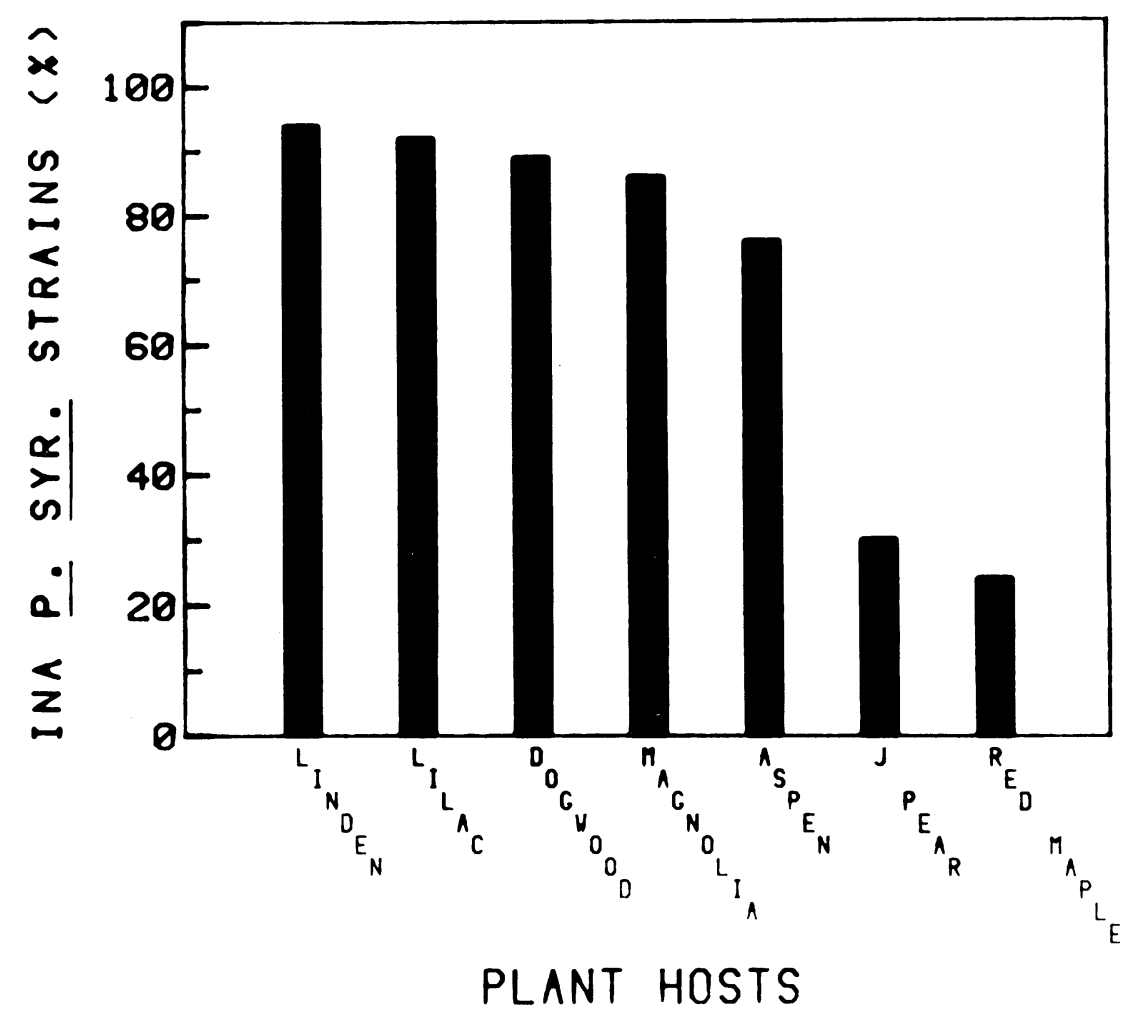

Fig. 1. Proportion of ice nucleation active $P$. syringae to total fluorescent pseudomonads tested. Number of strains tested per host include: lilac 14, linden 17, dogwood 18, aspen 21, magnolia 16, Japanese pear 47, and red maple 17. Red maples sampled during December 1981 to January 1982, all other strains isolated from February 1982 to July 1982.

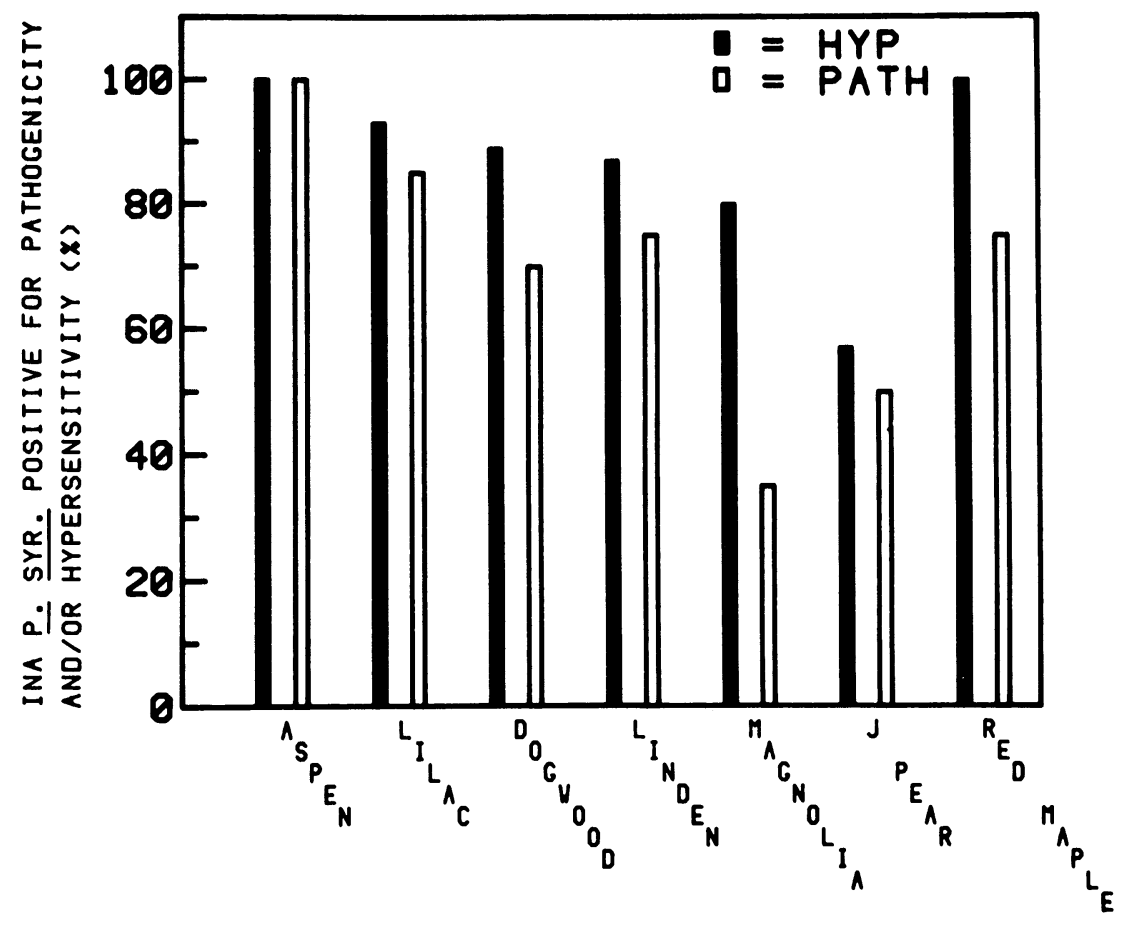

\section{PLANT HOSTS}

Fig. 2. Percentage of ice nucleation active strains per host expressing either the hypersensitive response in tobacco or pathogenicity in green fruit of yellow pear tomato relative to the total number of fluorescent pseudomonads tested. 
tomato fruit.

Combining both the HR or pathogenic responses as a measure of pathogenicity, the range of variation between INA strains and pathogenic strains is more easily observed (Fig. 3). In three hosts, linden $94 \%$ INA, lilac 93\% INA, and dogwood $88 \%$ INA, the proportion of strains potentially pathogenic were similar-linden $93 \%$ pathogenic, lilac 93\% pathogenic, and dogwood $89 \%$ pathogenic. This variation was greater in magnolia $75 \%$ INA and $88 \%$ pathogenic. This variation was greatest in maple and Japanese pear, where 30 and $24 \%$, respectively, were INA, whereas 60 and $77 \%$ of these strains were pathogenic in tomato fruit.

\section{DISCUSSION}

A large proportion of strains of $P$. syringae isolated from 40 of 44 woody plant species were INA. No INA strains of $P$. syringae were recovered in this survey from cultivars of either eucalyptus, aspen $95 \%$ INA and $76 \%$ pathogenic and

rhododendron, or ash sampled, even through $P$. syringae was isolated from diseased tissues of these plants. However, some strains from ash and eucalyptus were positive for either the $H R$ in tobacco or were pathogenic to excised immature fruit of yellow pear tomato.

Strains of INA $P$. syringae were the predominant species of bacterial ice nucleators recovered from these infected hosts. Several INA strains of fluorescent pseudomonads resembling $P$. fluorescens (oxidase and arginine dihydrolase positive) and an occasional nonfluorescent bacterial colony resembling Erwinia herbicola were isolated, but they were always a minor component of the INA species in a sample. This is consistent with observations by Lindow et al (10) and other researchers (5-7) on the distribution of INA bacteria in nature. Although $P$. syringae strains were recovered from blighted rhododendron blossoms, none were pathogenic in tomato fruit, induced an HR in tobacco, or were INA.

Table 1. Comparison of Pseudomonas syringae strains isolated from seven plant hosts relative to their ice nucleation activity (INA) and their ability to induce a hypersensitive response (HR) in tobacco

\begin{tabular}{lcccccccc}
\hline \hline & \multicolumn{8}{c}{ Host } \\
\cline { 2 - 9 } & $\begin{array}{c}\text { Lilac } \\
\mathbf{( 1 4 )}\end{array}$ & $\begin{array}{c}\text { Aspen } \\
(\mathbf{2 1})\end{array}$ & $\begin{array}{c}\text { Linden } \\
\mathbf{( 1 7 )}\end{array}$ & $\begin{array}{c}\text { Dogwood } \\
\mathbf{( 1 8 )}\end{array}$ & $\begin{array}{c}\text { Magnolia } \\
\mathbf{( 1 6 )}\end{array}$ & $\begin{array}{c}\text { Japanese Pear } \\
\mathbf{( 4 7 )}\end{array}$ & $\begin{array}{c}\text { Maple } \\
(\mathbf{1 7})\end{array}$ \\
\hline \% INA & 93 & 76 & 94 & 88 & 86 & 30 & 24 \\
\% HR & 86 & 95 & 88 & 100 & 80 & 57 & 76 \\
\% INA + HR & 72 & 76 & 76 & 83 & 78 & 17 & 24 \\
\% Neither INA/HR & 7 & 5 & 0 & 0 & 8 & 36 & 24 \\
\hline
\end{tabular}

${ }^{a}$ Number of strains tested.

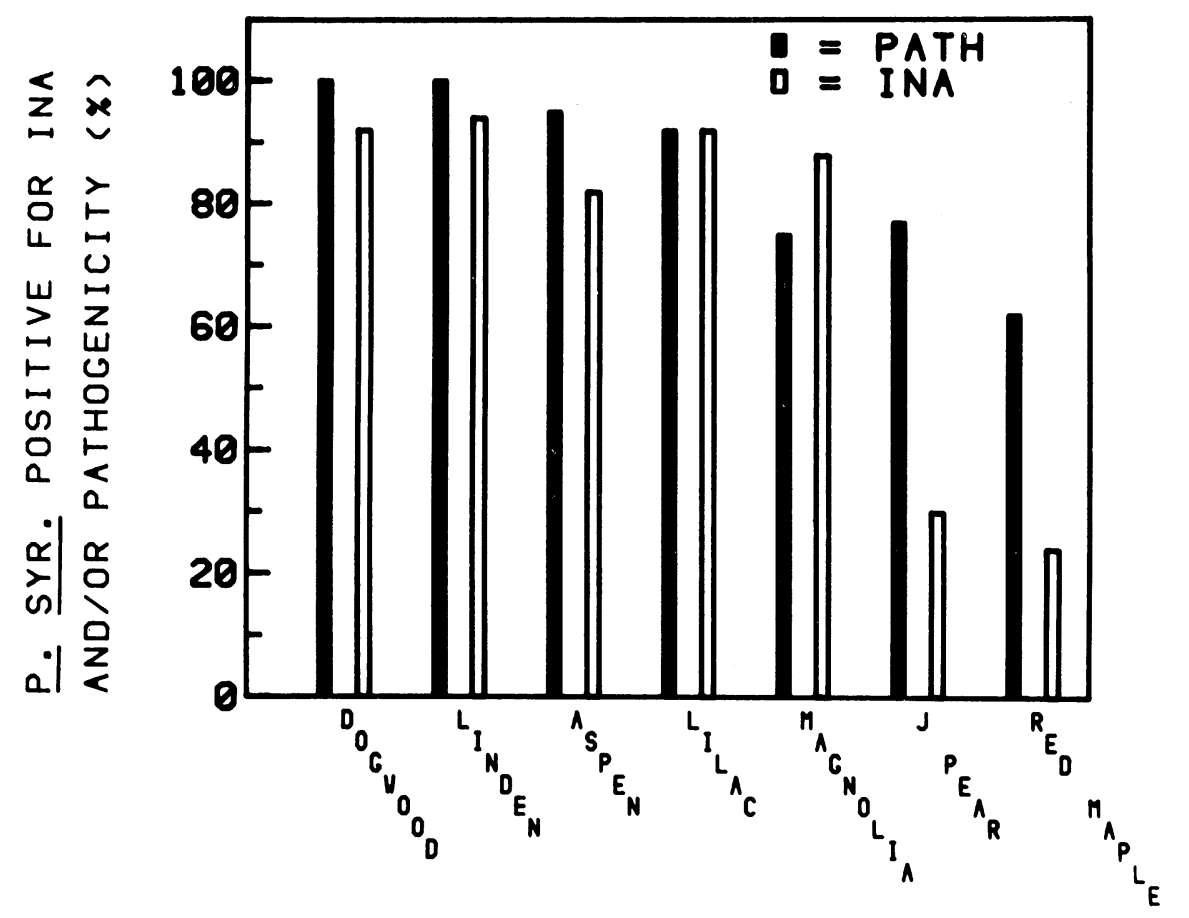

\section{PLANT HOSTS}

Fig. 3. Combined index of pathogenicity (pathogenic and/or hypersensitive response) vs. ice nucleation activity. Percentage of strains for each host testing positive for either trait relative to the total number of fluorescent pseudomonads tested.
The variability of occurrence of INA strains was particularly noticeable from the several hosts selected for this study. The low percentages of INA strains isolated from maple (Fig. 1) may have been due to an earlier sampling time than from the other hosts. The maple strains were isolated in December and January (1981 and 1982), whereas the rest were obtained from March to July 1982. However, the number of INA $P$. syringae strains isolated from Japanese pear at the later date was also low.

It is not known what effect the difference in sampling time might play in detecting the occurrence of INA strains of $P$. syringae on the different hosts or what role the prevailing environmental conditions play in the induction of the INA phenotype. Populations of $P$. syringae are often low to undetectable on most woody plants in the middle of winter, only to increase rapidly during the first few weeks of spring (S. Baca and L. W. Moore, unpublished).

Along with the variation observed in the distribution of the INA characteristic, variations in the $H R$ in tobacco and pathogenicity to green tomato fruit were also observed among strains of $P$. syringae isolated from different hosts.

Aspen was the only plant host where all INA $P$. syringae strains were also positive for both pathogenicity in tomato and HR in tobacco. This finding is of interest to us because one of the two reports of frost episodes preceding symptom development in Pacific Northwest nurseries involved aspen. The availability of aspen cultivars for landscape plantings has been reduced because of the susceptibility of this species to $P$. syringae infection in the nursery and the reluctance of many nursery operators to propagate so susceptible a plant species.

Based on our findings, we suggest that ice nucleation ability be considered a virulence factor that can contribute to pathogenesis but does not confer pathogenicity by its presence. We also find that not all strains of $P$. syringae in the nursery environment are pathogens or ice nucleators.

\section{ACKNOWLEDGMENTS}

We thank D. L. Coyier for his suggestions on form and content. We also thank the Oregon Nursery Advisory Council and the Horticulture Research Institute, Inc., for their financial grants, which provided funds for most of this research.

\section{LITERATURE CITED}

1. Cameron, H. R. 1962. Tech. Bull. Ore. Agric. Exp. Stn. 66.64 pp.

2. Cameron, H. R. 1970. Pseudomonas content of cherry trees. Phytopathology 60:1343-1346.

3. Canfield, M. L., Baca, S., and Moore, L. W. 1986. Isolation of Pseudomonas syringae from 40 cultivars of diseased woody plants with tip dieback in Pacific Northwest nurseries. Plant Dis. 70:647-650.

4. Dowler, W. M., and Weaver, D. J. 1975. Isolation and characterization of fluorescent pseudomonads from apparently healthy peach trees. Phytopathology 65:233-236. 
5. Endert, E., and Ritchie, D. F. 1984. Detection of pathogenicity, measurement of virulence, and determination of strain variation in Pseudomonas syringae pv. syringae. Plant Dis. 68:677-680.

6. Gross, D. C., Cody. Y. S., Proebsting, E. L., Jr., Radamaker, G. K., and Spotts, R. A. 1983. Ecotypes and pathogenicity of ice nucleationactive Pseudomonas syringae isolated from deciduous fruit tree orchards. Phytopathology 74:241-248.

7. Hirano, S. S., Maher, E. A., Kelman, A., and Upper, C. D. 1978. Ice nucleation activity of fluorescent plant pathogenic pseudomonads. Pages 717-724 in: Proc. Int. Conf. Plant Path. Bact. 4th. Stn. Pathol. Veg. Phytobacteriol., Gilbert-Clarey, France.

8. Klement, Z. 1963. Rapid detection of the pathogenicity of phytopathogenic pseudomonads. Nature (London) 199:299-300.

9. Klement, Z., Rozsnyay, D. S., and Arsenijevic,
M. 1974. Apoplexy of apricots. II. Relationship of winter frost and the bacterial canker and dieback of apricots. Acta Phytopathol. Acad. Sci. Hung. 9:35-45.

10. Lindow, S. E., Arny, D. C., and Upper, C. D. 1978. Distribution of ice nucleation-active bacteria on plants in nature. Appl. Environ. Microbiol. 36:831-838.

11. Lindow, S. E., Arny, D. C., and Upper, C. D. 1982. Bacterial ice nucleation: A factor in frost injury to plants. Plant Physiol. 70:1084-1089.

12. Maki, L. R., and Willoughby, K. J. 1978. Bacteria as biogenic sources of freezing nuclei. J. Appl. Meteorol. 17:1049-1053.

13. Panagopoulos, C. G., and Crosse, J. E. 1964. Frost injury as a predisposing factor in blossom blight of pear caused by Pseudomonas syringae van Hall. Nature (London) 202:1352.

14. Paulin, J. P., and Luisetti, J. 1978. Ice nucleation activity among phytopathogenic bacteria. Pages
725-731 in: Proc. Int. Conf. Plant Path. Bact. 4th. Stn. Pathol. Veg. Phytobacteriol. GilbertClarey, France.

15. Sabet, K. A. 1953. Studies on the bacteria dieback and canker disease of poplar. III Freezing in relation to the disease. Ann. Appl. Biol. 40:645-650.

16. Schaad, N. W., ed. 1980. Laboratory Guide for Identification of Plant Pathogenic Bacteria. American Phytopathological Society, St. Paul, MN. 72 pp.

17. Weaver, D. J., Gonzales, C. F., and English, H 1981. Ice nucleation by Pseudomonas syringae associated with canker production in peach Phytopathology 71:109-112.

18. Zeller, V. W., and Schmidle, A. 1979. The effect of frost on the infection by Pseudomonas syringae von Hall on leaves of sour cherries (Prunus cerasus). Nachrichtenbl. Dtsch. Pflanzenschutzdienstes (Braunschweig) 31:97-99. 